\title{
The changes in complete blood count in thyroid cancer patients treated with radioactive iodine ablation therapy
}

\author{
Radyoaktif iyot tedavisi alan tiroid kanserli hastalarda tam kan sayımı \\ değişiklikleri
}

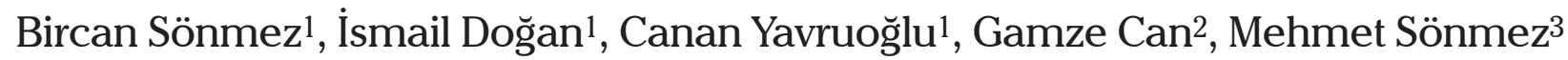 \\ ${ }^{1}$ Department of Nuclear Medicine, Karadeniz Technical University School of Medicine, Trabzon, Turkey \\ 2Department of Public Health, Karadeniz Technical University School of Medicine, Trabzon, Turkey \\ ${ }^{3}$ Department of Hematology, Karadeniz Technical University School of Medicine, Trabzon, Turkey
}

\begin{abstract}
Objective: The aim of this study was to evaluate the effect of radioactive iodine (RAI) ablation therapy on the complete blood count (CBC) in thyroid cancer patients.

Materials and Methods: One hundred sixty four patients undergoing RAI ablation therapy after total thyroidectomy were included. $\mathrm{CBC}$ results were available from the patients' medical records at the time of ablation and at the $1^{\text {st }}, 6^{\text {th }}$, and $12^{\text {th }}$ months after RAI therapy.

Results: Hemoglobin (Hb), white blood cell (WBC) and platelet (Plt) values were significantly lower than baseline at 1 month after treatment $(\mathrm{p}<0.0001)$. $\mathrm{Hb}$ and $\mathrm{WBC}$ values were increased at the $6^{\text {th }}$ month and at the $1^{\text {st }}$ year. Plt values increased at the $6^{\text {th }}$ month but had decreased again at the $1^{\text {st }}$ year. The values were usually in normal ranges except in the patients with low pretreatment $\mathrm{Hb}$ and $\mathrm{WBC}$ values.

Conclusion: RAI ablation therapy in thyroid cancer patients is a safe treatment modality without any serious or persistent hematological side effects. (Turk J Hematol 2010; 27: 269-74)
\end{abstract}

Key words: Radioactive iodine therapy, complete blood count, thyroid cancer

Received: June 1, 2010

Accepted: July 26, 2010

\section{Özet}

Amaç: Bu çalışmanın amacı total tiroidektomi sonrası artakalan tiroid dokusu için radyoaktif iyot (RAI) tedavisi alan tiroid kanserli hastalarda tam kan sayımındaki değişimleri değerlendimek.

Yöntem ve Gereçler: Total tiroidektomi sonrası RAI tedavisi almıs 164 hasta değerlendirildi. Hastaların tedaviden önce ve tedavi sonrası 1. ay, 6. ay ve 12. ay hemoglobin (Hb), lökosit (WBC) ve trombosit (PIt) düzeyleri değerlendirildi.

Bulgular: RAI tedavisinden 1 ay sonra $\mathrm{Hb}, \mathrm{WBC}$ ve Plt değerlerinde anlamlı bir azalma izlendi. Plt sayısı 6. ayda düzelirken 1. ylda tekrar azaldı. Buna karşıllk $\mathrm{Hb}$ ve WBC değerlerinde ilk ayda gözlenen azalma 
6. ay ve 1. yılda izlenmedi. Ancak izlenen bu değişiklikler tedavi öncesi değerleri düşük hastalar hariç normal sınırlar içindeydi.

Sonuç: Tiroid kanserli hastalarda RAI tedavisi ciddi bir hematolojik yan etkiye yol açmaksızın güvenilir bir tedavi yöntemidir. (Turk J Hematol 2010; 27: 269-74)

Anahtar kelimeler: Radioaktif iyod tedavi, tam kan sayımı, tiroid kanseri

Geliş tarihi: 1 Haziran 2010

Kabul tarihi: 26 Temmuz 2010

\section{Introduction}

Treatment of differentiated thyroid cancer (DTC) with radioactive iodine (RAI) is a standard procedure for the ablation of remnant thyroid tissue following surgery and for the treatment of iodine-avid metastases [1]. Usually, high doses of RAI (100-150 $\mathrm{mCi}$ ) are used for total ablation of thyroid remnants. RAI treatments may be repeated especially in metastatic patients, and this delivers high cumulative doses to non-thyroid organs. The side effects of RAI treatment may occur in many areas and organ systems. The most common side effect is a decreased saliva production, but severe long-term side effects are rare. Other organ-specific side effects are found in the lacrimal glands, bone marrow, lungs, and reproductive organs. Incidence of secondary malignancies and leukemia might increase with higher RAI doses [2,3].

Bone marrow suppression can arise after RAI treatment [4]. There are many factors that affect the frequency and severity of bone marrow suppression. These include the prescribed and total cumulative RAI doses, frequency of treatments and clearance rate of RAI therapy, and additively, the patient's bone marrow reserve and degree of bone marrow metastases [2]. Although bone marrow suppression with repeated high-dose RAI treatments is reported [5,6], changes in the peripheral complete blood count (CBC) after an initial RAI ablation treatment is not well defined. Therefore, we retrospectively evaluated the hemoglobin ( $\mathrm{Hb})$, platelet (PIt) and white blood cell (WBC) counts before ablation and at the $1^{\text {st }}$ month, $6^{\text {th }}$ month and $1^{\text {st }}$ year following initial RAI ablation treatment.

\section{Materials and Methods}

One hundred and sixty-four patients undergoing RAI remnant ablation therapy after total thyroidectomy were retrospectively evaluated. Gender, age and demographic characteristics were recorded. The patient's CBC results were available in the medical records at the time of ablation and at the $1^{\text {st }}$ and $6^{\text {th }}$ months and $1^{\text {st }}$ year after RAI therapy. Patients taking any medications known to affect the $\mathrm{CBC}$; having any hematological conditions; and/or receiving a second dose of RAI during the first-year follow-up or external beam radiotherapy or chemotherapy before RAI therapy or within 1 year after ablation were excluded from the study. None of the patients had bone marrow metastases, but one patient had pulmonary metastases and seven patients had lymph node metastases. Levothyroxine (L-T4) and triiodothyronine (L-T3) treatments were discontinued after 4-6 weeks and 2 weeks, respectively, and a low-iodine diet for 2 weeks was recommended before RAI treatment. None of the patients was prepared for RAI ablation with recombinant human thyroid stimulating hormone (rhTSH). After total thyroidectomy, RAI remnant ablation treatment with standard-high RAI doses [3.7-7.4 GBq (100-200 $\mathrm{mCi}$ ]] was performed in 6-8 weeks. RAI therapy was administered as follows: 122 patients (74.4\%), 37 patients (22.6\%), and 5 patients (3\%) received $100 \mathrm{mCi}, 125-150 \mathrm{mCi}$, and $175-200 \mathrm{mCi}$, respectively. L-T4 treatment was restarted after 48 hours. Diagnostic imaging with low-dose RAI (2-5 mCi) was performed within 6-12 months. However, no second RAI treatment or radiotherapy was applied during the one-year follow-up. All blood tests were analyzed with Full Automated CBC analyzer (Beckman Coulter LH-750). Hb reference values were $13-17 \mathrm{~g} / \mathrm{dl}$ and $11.5-16 \mathrm{~g} / \mathrm{dl}$ for males and females, respectively. WBC and Plt count reference values were $4.8-10.8 \times 10^{3} / \mathrm{UL}$ and $130-400 \times 10^{3} / \mathrm{UL}$, respectively. Written informed consent was obtained from the patients.

\section{Statistical Analysis}

Data are presented as the mean \pm standard deviation (SD); medians with ranges are given when 
appropriate. Continuous variables were compared using repeated measures variance analysis for changing over time. Bonferroni test was used for post-hoc analysis. CBC values between RAI groups were compared by Student's $t$ test. $\mathrm{p}<0.05$ was considered statistically significant. All statistical analyses were performed using SPSS version 13.01 for Windows.

\section{Results}

The mean age of patients (24 males, 68 females) was $47 \pm 13$ years (range: $22-81$ years). The baseline characteristics of the patients are presented in Table 1. Median TSH level was $82 \mathrm{mU} / \mathrm{L}$ (range: $32-100$ $\mathrm{mU} / \mathrm{L}$ ) because of cessation of L-T4 or L-T3 treatments. Hb (Males/Females), WBC, and Plt values were significantly lower than baseline at 1 month after treatment $(\mathrm{p}<0.0001) . \mathrm{Hb}$ and WBC values had increased at the $6^{\text {th }}$ month and $1^{\text {st }}$ year. The decreases in the $\mathrm{Hb}$ levels were not different between the male and female patients. Similarly, it was observed that neutrophil and lymphocyte counts decreased equally. Plt values increased at the $6^{\text {th }}$ month, but decreased again at the $1^{\text {st }}$ year (Table 2, Figure 1a, b). There was no requirement of blood transfusion or febrile neutropenia occurrence in any of the patients. Although all hematological parameters decreased at the $1^{\text {st }}$ month and for Plt also at the $1^{\text {st }}$ year, the values were usually in normal ranges except for those patients with low pretreatment $\mathrm{Hb}$ and $\mathrm{WBC}$ values. Before treatment, $\mathrm{Hb}$ values were low in 21 patients $(12.8 \%, 8$ males, 13 females) while WBC values were low in 7 patients (4.3\%); no patients had iron, vitamin B12 or folate deficiency. The change in $\mathrm{Hb}$ and $\mathrm{WBC}$ values is probably related to the disease status or the medications used before (Table 3). No significant difference in the decreasing rate was found between patients with low pretreatment and normal pretreatment $\mathrm{Hb}$ and WBC counts. Similarly, there was no significant difference when comparing patients receiving different doses of RAI therapy. No complications were observed.

\section{Discussion}

Bone marrow suppression is a serious and, if not diagnosed, potentially life- threatening complica-
Table 1. Baseline characteristics of patients

\begin{tabular}{lc}
\hline Characteristics & \\
\hline Age & $47 \pm 13$ \\
Histology & $152(92.7 \%)$ \\
PTC & $11(6.7 \%)$ \\
FTC & $1(0.6 \%)$ \\
HCC & \\
TNM Stage & $130(79.3 \%)$ \\
I & $20(12.2 \%)$ \\
II & $13(7.9 \%)$ \\
III & $1(0.6 \%)$ \\
IV & \\
Administered Activity (MBq/mCi) & $4144 \pm 851(112.74 \pm 23)$ \\
Mean \pm SD & $3700(100)$ \\
Median & $3700-7400(100-200)$ \\
Range & \\
Post-Therapy Scan & $156(95.1 \%)$ \\
Thyroid remnant & $7(4.3 \%)$ \\
Lymph node metastases & $1(0.6 \%)$ \\
Pulmonary metastases & $0(0 \%)$ \\
Bone metastases & \\
\hline PTC: Papillary thyroid cancer; FTC: Follicular thyroid carcinoma; HCC: Thyroid carcinoma, \\
Hurthle cell; TNM: TNM staging system (tumor, node, metastasis
\end{tabular}

Table 2. CBC changes with RAI therapy

\begin{tabular}{|c|c|c|c|c|}
\hline & Pre-treatment & $1^{\text {st }}$ Month & $6^{\text {th }}$ Month & $1^{\text {st }}$ Year \\
\hline \multicolumn{5}{|c|}{$\mathrm{Hb}(\mathrm{g} / \mathrm{dl}) / \mathrm{M}$} \\
\hline Mean \pm SD & $13.7 \pm 1.9 \mathrm{a}, \mathrm{b}$ & $13.3 \pm 1.8^{c, d}$ & $13.5 \pm 1.9$ & $13.8 \pm 1.9$ \\
\hline Median & 14 & 13.6 & 13.8 & 14 \\
\hline Range & $9.1-16.8$ & $8.8-15.4$ & $7.9-16$ & $9.1-16.2$ \\
\hline \multicolumn{5}{|l|}{$\mathrm{Hb}(\mathrm{g} / \mathrm{dl}) / \mathrm{F}$} \\
\hline Mean \pm SD & $13.4 \pm 1.2^{\mathrm{a}, \mathrm{b}}$ & $6.7 \pm 1.9^{\mathrm{a}}$ & $12.6 \pm 1.1^{\mathrm{c}, \mathrm{d}}$ & $6.0 \pm 1.8^{\mathrm{e}}$ \\
\hline Median & 13.2 & 6.4 & 12.8 & 5.8 \\
\hline Range & $9.4-16.4$ & $2.5-16.7$ & $8.6-15.2$ & $1.7-12.9$ \\
\hline \multicolumn{5}{|c|}{$\mathrm{WBC}\left(10^{3} / \mu \mathrm{L}\right)$} \\
\hline Mean \pm SD & $12.9 \pm 1.1$ & $6.5 \pm 2.6$ & $13.2 \pm 1$ & $6.5 \pm 1.7$ \\
\hline Median & 13 & 6.1 & 13 & 6.3 \\
\hline Range & $9.6-15.4$ & $3.0-28.6$ & $10.5-15.9$ & $3.3-15.7$ \\
\hline $\mathrm{N} / \mathrm{L}$ & $3.9 \pm 1.5 / 2.1 \pm 0.6$ & $3.7 \pm 1.5 / 1.6 \pm 0.5$ & $4 \pm 2.4 / 1.8 \pm 0.5$ & $4 \pm 1.5 / 1.9 \pm 0.5$ \\
\hline \multicolumn{5}{|l|}{ Plt $\left(10^{3 / \mu \mathrm{L})}\right.$} \\
\hline Mean \pm SD & $289 \pm 71^{a, f, g}$ & $259 \pm 57$ & $265 \pm 62 \mathrm{~h}$ & $258 \pm 65$ \\
\hline Median & 285 & 258 & 265 & 255 \\
\hline Range & $152-538$ & $142-423$ & $134-422$ & $135-498$ \\
\hline \multicolumn{5}{|c|}{ 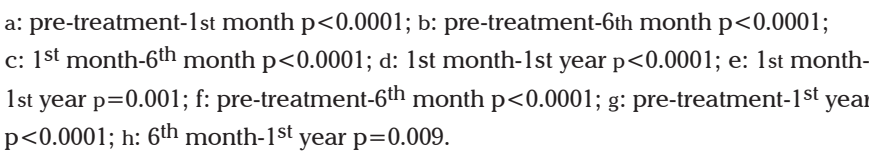 } \\
\hline
\end{tabular}

Hb/M: Hemoglobin/males; Hb/F: Hemoglobin/females; WBC: White blood cell; PIt: Platelets; N/L: Neutrophils/lymphocytes 


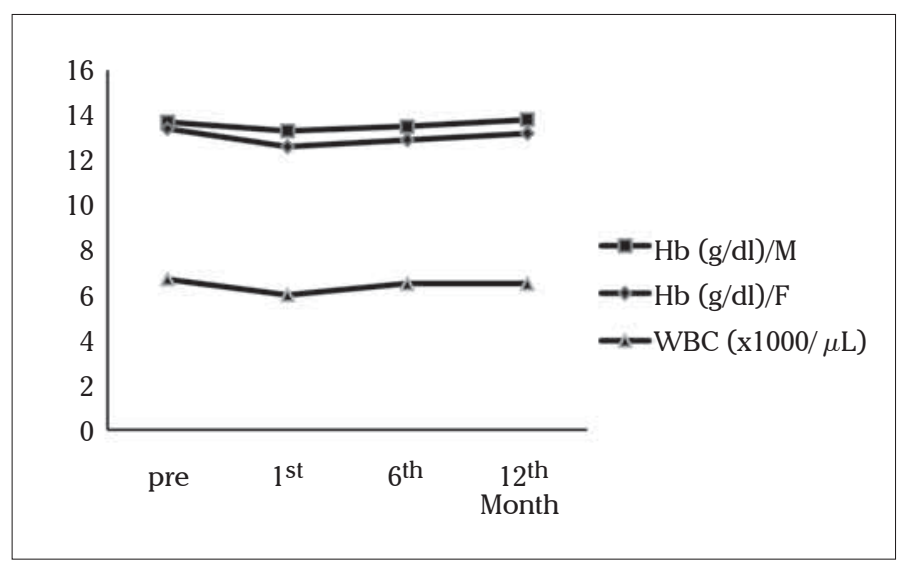

Figure 1a. Hb and WBC changes with RAI therapy

Table 3. CBC changes in the patients with low $\mathrm{Hb}$ and $\mathrm{WBC}$ values

\begin{tabular}{|c|c|c|c|c|}
\hline & Pre-treatment & $1^{\text {st }}$ Month & $6^{\text {th }}$ Month & $1^{\text {st }}$ Year \\
\hline \multicolumn{5}{|l|}{$\mathrm{Hb}(\mathrm{g} / \mathrm{dl}) / \mathrm{M}$} \\
\hline Mean \pm SD & $11.5 \pm 1.3$ & $11.3 \pm 1.4$ & $11.3 \pm 1.9$ & $12.1 \pm 1.3$ \\
\hline Median & 11.7 & 11.3 & 11.4 & 12.2 \\
\hline Range & $9.1-12.9$ & $8.8-13$ & $7.9-14.1$ & $10.4-14.1$ \\
\hline \multicolumn{5}{|l|}{$\mathrm{Hb}(\mathrm{g} / \mathrm{dl}) / \mathrm{F}$} \\
\hline Mean \pm SD & $10.7 \pm 0.7$ & $10.6 \pm 1.1$ & $11.2 \pm 1.1$ & $11.8 \pm 1$ \\
\hline Median & 11 & 10.9 & 11.1 & 11.8 \\
\hline Range & $9.4-11.5$ & $8.6-11.9$ & $9.6-13.4$ & $10.5-14.4$ \\
\hline \multicolumn{5}{|c|}{$\mathrm{WBC}\left(10^{3} / \mu \mathrm{L}\right)$} \\
\hline Mean \pm SD & $3.4 \pm 0.5$ & $3.6 \pm 0.9$ & $4.4 \pm 0.5$ & $4.2 \pm 0.7$ \\
\hline Median & 3.4 & 3.9 & 4.4 & 4.2 \\
\hline Range & $2.5-4$ & $1.7-4.4$ & $3.5-5.1$ & $3.3-5.3$ \\
\hline
\end{tabular}

Hb/M: Hemoglobin/males; Hb/F: Hemoglobin/females; WBC: White blood cell

tion of RAI treatment. Transient leukopenia, anemia and thrombocytopenia may be observed after RAI administration, but severe cytopenia is usually seen with high doses of RAI ( $>600 \mathrm{mCi}$ ) [7]. The World Health Organization classification is used for bone marrow suppression after RAI treatment. While mild and reversible blood count alternations are observed in grade I-II, persistent severe cytopenia and aplasia or acute myeloid leukemia are detected in grade III and grade IV, respectively. Although RAI therapy induces chromosome damage in the lymphocytes, the effect of RAI depends on lymphocyte phenotype and RAI activity. Natural killer cells are most sensitive, followed by B lymphocytes and T-helper lymphocytes. However, these do not result clinically in an immunosuppression [8,9]. Severe and permanent bone marrow suppression was reported by Benua et al. [10] in 8 of 59 patients treated with RAI. In the dosimetric evaluations, six of these eight patients received in excess of 3Gy (300

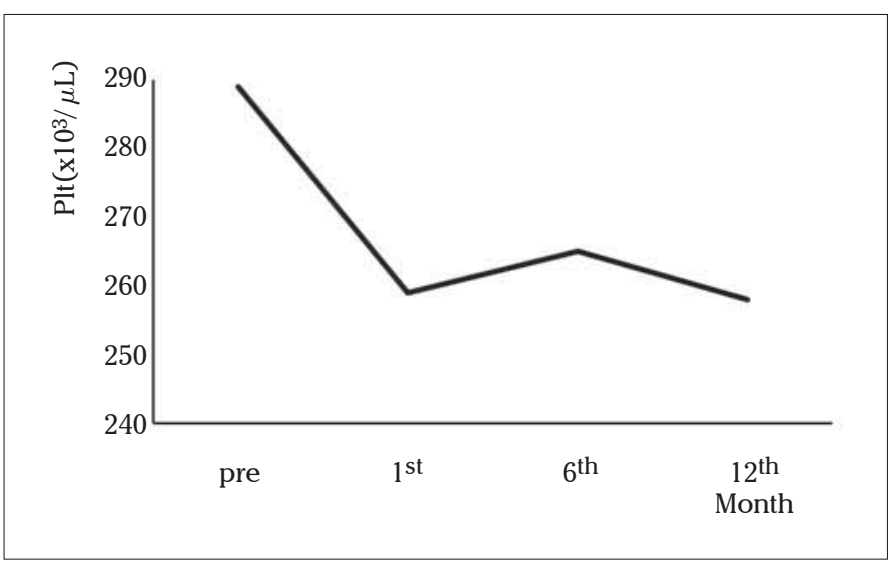

Figure 1b. Plt changes with RAI therapy

rads) to the blood. When using $2 \mathrm{~Gy}$ (200 rads) to the blood as the upper limit, Von Nostrand et al. [11] found that mild transient decreases in blood cell counts were seen in $90 \%$ of the patients. We usually applied $100 \mathrm{mCi}$ RAI and the dose usually did not exceed 2Gy.

Hypothyroid patients have an increased serum creatine and decreased glomerular filtration rate. Decreased renal clearance results in increased RAI retention. Therefore, the bone marrow-absorbed dose after treatment with RAI would be expected to be lower for patients given rhTSH, which is protective for hypothyroidism and additionally may reduce the half-life of RAI, than for patients subjected to L-T4 withdrawal [12-14]. Molinaro et al. [15] reported recently that RAI ablation treatment is associated with a decline in WBC and Plt that persists for at least one year after ablation without differences between the rhTSH and the L-T4 withdrawal groups. On the other hand, Rosario et al. [16] demonstrated that the decrease in WBC and platelets in the first three months was significantly lower in the rhTSH group than in the L-T4 withdrawal group. This suggests that the transient effects on the bone marrow may be more of a dose-related phenomenon, while the late persistent effects are more influenced by individual susceptibility. In this study, we documented that $\mathrm{Hb}$, WBC, and Plt counts in the first month were decreased, but did not persist for a long time. The patients with low pre-treatment $\mathrm{Hb}$ and WBC values were not more susceptible to the suppressive effect of the treatment than the patients having normal values. Although statistically significant, the decreases in $\mathrm{Hb}, \mathrm{WBC}$ and Plt were small and without evidence of clinical importance. Interestingly, 
Plt counts were slightly decreased at the $1^{\text {st }}$ year, similar to the observation of Molinaro et al. [15], but different from their report, we think that the decreased Plt count was probably associated with the low-dose RAI (2-5 mCi) applied for diagnostic imaging at 6-12 months. Although CBC values were normal after RAI treatment, the statistical results showed that RAI doses were important for bone marrow suppression. Therefore, physicians should be careful regarding additive or overdoses.

Sublethal radiation doses damage bone marrow cells and may lead to leukemia. Acute and chronic myeloid leukemia were reported with RAI treatment, especially in those with bone metastasis. Incidence of leukemia was increased in the patients who received more than $800 \mathrm{mCi}$, were $>45$ years and were treated within short intervals. Only very rarely is acute leukemia found in patients receiving a small RAI dose of $<300 \mathrm{mCi}$ [17-19]. Similarly, we did not observe the development of an acute or chronic myeloid leukemia due to RAI treatment within one year. However, the long-term outcome of RAI therapy may be different from these results.

In conclusion, we suggest that RAI therapy can be associated with slight and reversible changes in $\mathrm{Hb}, \mathrm{WBC}$ and Plt counts; however, it is a safe treatment modality for ablation without any serious or persistent hematological side effects.

\section{Conflict of interest}

No author of this paper has a conflict of interest, including specific financial interests, relationships, and/or affiliations relevant to the subject matter or materials included in this manuscript.

\section{References}

1. Cooper DS, Doherty GM, Haugen BR, Kloos RT, Lee SL, Mandel SJ, Mazzaferri EL, McIver B, Pacini F, Schlumberger M, Sherman SI, Steward DL, Tuttle RM. Revised American Thyroid Association management guidelines for patients with thyroid nodules and differentiated thyroid cancer. Thyroid 2009;19:1167-214.

2. Van Nostrand D. The benefits and risks of I-131 therapy in patients with well-differentiated thyroid cancer. Thyroid 2009;19:1381-91.

3. Sawka AM, Thabane L, Parlea L, Ibrahim-Zada I, Tsang RW, Brierley JD, Straus S, Ezzat S, Goldstein DP. Second primary malignancy risk after radioactive iodine treatment for thyroid cancer: a systematic review and meta-analysis. Thyroid 2009;19:451-7.
4. Van Nostrand D, Freitas J. Side effects of I-131 for ablation and treatment of well-differentiated thyroid carcinoma. In: Wartofsky L, Van Nostrand D, editors. Thyroid Cancer: A Comprehensive Guide to Clinical Management. Totowa, NJ: Humana Press, 2006: 459-84.

5. Menzel C, Grünwald F, Schomburg A, Palmedo $\mathrm{H}$, Bender H, Späth G, Biersack HJ. "High-dose" radioiodine therapy in advanced differentiated thyroid carcinoma. J Nucl Med 1996;37:1496-503.

6. Dorn R, Kopp J, Vogt H, Heidenreich P, Carroll RG, Gulec SA. Dosimetry-guided radioactive iodine treatment in patients with metastatic differentiated thyroid cancer: largest safe dose using a risk-adapted approach. J Nucl Med 2003;44:451-6.

7. Chow SM. Side effects of high-dose radioactive iodine for ablation or treatment of differentiated thyroid carcinoma. J HK Coll Radiol 2005;8:127-35.

8. Gutiérrez S, Carbonell E, Galofré P, Creus A, Marcos R. Cytogenetic damage after 131-iodine treatment for hyperthyroidism and thyroid cancer. A study using the micronucleus test. Eur J Nucl Med 1999;26:1589-96.

9. Tofani A, Sciuto R, Cioffi RP, Pasqualoni R, Rea S, Festa A, Gandolfo GM, Arista MC, Maini CL. Radioiodineinduced changes in lymphocyte subsets in patients with differentiated thyroid carcinoma. Eur J Nucl Med 1999;26:824-9.

10. Benua RS, Cicale NR, Sonenberg M, Rawson RW. The relation of radioiodine dosimetry to results and complications in the treatment of metastatic thyroid cancer. Am J Roentgenol Radium Ther Nucl Med 1962;87:171-82.

11. Van Nostrand D, Neutze J, Atkins F. Side effects of "rational dose" iodine-131 therapy for metastatic welldifferentiated thyroid carcinoma. J Nucl Med 1986;27:1519-27.

12. de Keizer B, Hoekstra A, Konijnenberg MW, de Vos F, Lambert B, van Rijk PP, Lips CJ, de Klerk JM. Bone marrow dosimetry and safety of high 131I activities given after recombinant human thyroid-stimulating hormone to treat metastatic differentiated thyroid cancer. J Nucl Med 2004;45:1549-54.

13. Hänscheid $\mathrm{H}$, Lassmann $\mathrm{M}$, Luster $\mathrm{M}$, Thomas SR, Pacini F, Ceccarelli C, Ladenson PW, Wahl RL, Schlumberger M, Ricard M, Driedger A, Kloos RT, Sherman SI, Haugen BR, Carriere V, Corone C, Reiners C. Iodine biokinetics and dosimetry in radioiodine therapy of thyroid cancer: procedures and results of a prospective international controlled study of ablation after rhTSH or hormone withdrawal. J Nucl Med 2006;47:648-54.

14. Menzel C, Kranert WT, Döbert N, Diehl M, Fietz T, Hamscho N, Berner U, Grünwald F. rhTSH stimulation before radioiodine therapy in thyroid cancer reduces the effective half-life of (131)I. J Nucl Med 2003;44:1065-8. 
15. Molinaro E, Leboeuf R, Shue B, Martorella AJ, Fleisher M, Larson S, Tuttle RM. Mild decreases in white blood cell and platelet counts are present one year after radioactive iodine remnant ablation. Thyroid 2009;19:1035-41.

16. Rosário PW, Borges MA, Purisch S. Preparation with recombinant human thyroid-stimulating hormone for thyroid remnant ablation with 131I is associated with lowered radiotoxicity. J Nucl Med 2008;49:1776-82.

17. Petrich T, Widjaja A, Musholt TJ, Hofmann M, Brunkhorst T, Ehrenheim C, Oetting G, Knapp WH. Outcome after radioiodine therapy in 107 patients with differentiated thyroid carcinoma and initial bone metastases: side-effects and influence of age. Eur J Nucl Med 2001;28:203-8.

18. Ankit J, Premalata CS, Saini KS, Bapsy PP, Sajeevan KV, Singh T, Batra U, Govind B, Dasappa L, Atilli S, Permeshwar R. Acute myeloid leukemia following radioactive iodine therapy for papillary carcinoma of the thyroid. Turk J Hematol 2009;26:97-9.

19. Yoosufani Z, Slavin JD Jr, Hellman RM, Sethi SS, Spencer RP. Preleukemia following large dose radioiodide therapy for metastatic thyroid carcinoma. J Nucl Med 1987;28:1348-50. 